\title{
家族的に簇發せる
}

\author{
京都府立管科大學耳鼻咽喉科教宔(主任 巾村登教授)
}

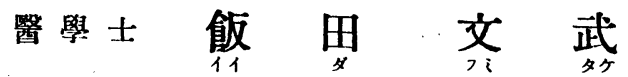

緒言

しアフタา性口內炎は臨床的站飞病理解剖的に 見て興味深い問題である．其の確固たる病原は 爾來多數の學者により研究されてねるに拘らず 倘不明である，從つて命名は勿論, 臨床的觀察 病理解剖，治療法の諸點飞就て從來學者の意見 は區々で決定的のるのはない。

1840年に，Bressler は 6 種の名稃を與へて居

\section{る. 即ち}

1. Stomatitis folliculosa

2. Stomatitis aphthosa

3. Aphthae

4. phlyctäre Oris ulcerosa

5. aphthöse Mundentzündung

6. Schwämmchen

等であるが，是は醫學の極めて幼稚な時代をる ため口腔內の一切の粘膜炎症を悉く包括して居 る漾である。

1898年には Mikulicz 及び Kümmel の兩氏 はレアフタา性口內炎を定義し, 而して別個に慢 性再發性しアフタา 症 chronische rezidivierende Aphthen なる病名を下し，通常のレアフタา性口 內炎と區別してるる.

1902年には Krans が Fränkel の提言飞贊成 して Stomatitis fibrinosa maculosa の名稱を用ひ 1903年には Trautmann が本疾患之哺乳，妊娠， 月桱との關係を論じ Lang の所謂 Stomatitis uterina をる名稱を揭げて居る.
1907年には Cruet がロ蹄疫としてしアフタา性 口內炎と云ひ，更に1910年 Roque 及び Galliard は口腔內疾病署上七アフタ性口内炎を 2 種に分 ち，其の一は局所損傷によるものであつて，一 般に云ふ所謂しアフタา病であつて原因としては 口腔粘膜の器栈的, 或は化學的の刺戟に上り起 るものであり。他の一は全身疾病の口冈現像と してのレアフタ性口內炎に屬するものであると 云つて居る.

1911年には Kaufmann はレアフタา性口內炎の 名稱を主張して, 而して之を義膜性口内炎と論 ビて居る。

1914年 Moure 及び Brindel はレアフタาのロ 腔及び咽頭粘膜に發生する場合は之をしアフタา 性しアンギナフと云ひ，口腔粘膜にのみ發生する 場合は之をしアフタ性口冈炎と云つてるる.

以上の如く, 其の名稱は種々雜多であり, 其 の據點とする所は認められるる，是等の名稱 より吾人は果して䢐の概念を得る事は困難であ る.

私は最近中村臨床に於て一家族中上り 4 人の しアフタフ性口內炎を出したる症例を經驗したの で此に報告する次第である。

\section{症例}

患者 口某，7歲，男子，梅府.

蒙族愿 雨親は健康にして著忠を知らない，且又还

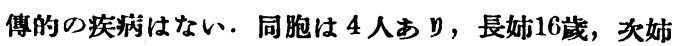
13歳，兄は11歲，姉 2 人は特記すでき疾患にかつつた 事なく，兄は左下肢の骨醚炎に现在䍜って，手術を受 
けて良好なる繞過をとつてるる。

既往病艇 生來健康にて著患を知らない。

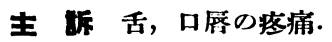

現病厢9月20日顷より頭痛，胃腸障碍を訴一舌尖 端部に白色の小苔あるを認め, 其部に疼痛を訴人食事 に際して特に甚しく，食事取極度に障嘫される゚に至 y9月26日К入院した.

初唫時所見 體格，榮共に中等度，皮虏，可見粘 膜には貧血は見られず，愐部淋巴腺は 2,3 個小指頭大 のものを触知する.胸部, 腹部臟器には異狀なし.

同所火晃上口原, 下口辰の前方, 舌尖端部, 右上

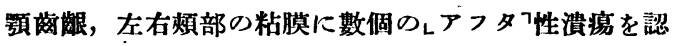
め，其部の苔より叙抹標本を作り顯微鏡檢查により多 數の葡萄狀球菌，双球菌，口腔レスピロへータフを認め， レアがールフ培養よりは其の外に連鎖狀球菌も證明す る. 體溫は $36.5^{\circ} \mathrm{C}$, 咽頭及び喉頭粘膜は多少充血して るるが，しアフタา性溳瘍は認めない. 尿は弱酸性, 黄 色透明, 蛋白, 糖反應は陰性である. 賚便中には䖵卵， 潜血反應は陰性である。血像は川性啫好性白血球の暂 加は認められず，淋巴球が稍々筧加して居る。

\begin{tabular}{|lc|}
\hline Erythrozytengesammtzahl & \\
Haemoglobingehalt & $80 \%$ (Sahli) \\
Leukozytengesammtzahl & 6200 \\
neutrophile Z. & $59 \%$ \\
Lymphozyten & $35 \%$ \\
eosinophile Z. & $1 \%$ \\
basophile Z. & $0 \%$ \\
gr. Mon. u. Ueb. & $5 \%$ \\
\hline
\end{tabular}

骰㴊は潰痬の狀㑷の特有なる束より，又鏡检上口队 常住菌のみ認められる事によりレアフタา性口内炎なる 事は容易である。

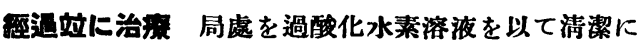
し，且つ $5 \%$ 确酸銀溶液，0.1\%レトリパフラビン7滨

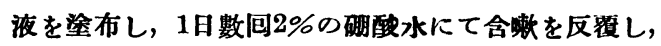
なほょヴイタミンフB製劑，酻母製劑を內服せしめたる 戱, 局所症狀は日を迫ふて良好となり，治療開始後 5 日後には何等痕跡を残さずして全治した。

患者入院山にその雨親，同家の使用人の口腔を检す るに何等異狀を認めない. 併し 2 人の姉と兄にしアフ タา性口内炎を證明する.郎ち，17歲の長姉は舌，

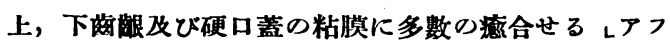

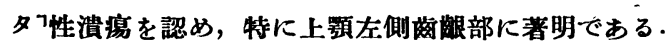
13葴の次姉は下口厎の左側に 3 倜のレアフタา性清瘍あ

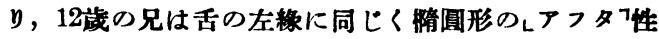

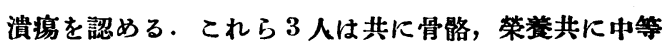
度, 皮店, 粘膜の筫血もなく, 胸部, 腹部牶器は何等 異狀を認めないが，兄，姉 3 人共周腸障礙を訴一て居

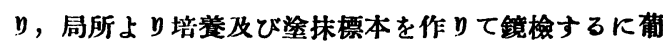
萄狀球菌，双球菌，口腔しスピロニータาを認める。血 像，尿共暴狀を認めない。

各何れもしアフタา性口内炎の診嗍の下に第 1 患者と 同㥞に治療を施した所，總て 4,5日の後に輕快に赴き 1 䓢間後には全治した。

\section{考按}

本疾病の原因に就て從來也飞と論ぜられて居 り, 本病の臨床的經驗により多少共に傳染病的 の性質は否認し難いと云はれて居るが，其の起 炎菌が何であるかは確定してなないが，口蹄疫 とは關係があり，現今佛蘭西及英國學派に於て はレアフタา性口內炎を口蹄㿆と見做す傾向があ る. 然るに獨逸に於ては少數の者の外は本病を 獨立の疾患之見做し，特有の起炎菌を主張して 居る梯である。

1763年に Sagar は本病と口蹄疫との關係に注 目しその傅染は牛乳によるものであると云つて みる。

1884年 Herweg, Mann, Willhelm 及び Steierlin, Siegel の諸氏はこの方面の實驗的研究に着手し て居り, Lehmann, Neumann はその共著の L細 菌學רに於て Febris aphthosa なる一疾患を舉 げてみる．然しての方面の研兊は盛んであるが 確定せる說は學い样である。

余の症例に於て見るやうな葡萄狀球菌, 連鎖 狀球菌, 双球菌, 口腔しスピ口へータフの如き細 菌を以て病原菌であると見做す人々は Fränkel を始め Leni, Neumann があり，Klein は双球 菌說を主張して居る。

Stooss は双球菌, 連鎖狀球菌によつて13例に 
於て本病を弡來せしめたと報告してるる． 又 Busseneus は Bacillus aphthosus の存在を稱へ, Goadby は連鎖狀球菌を病原菌之云つてみる. 然るに Gansはょアフタาより取つた分泌物質 を家鬼の角膜に接種する事に成功してるるが, Tempelton はレアフタフ性口內炎と單純性 レヘル ペスフとの關係を研究するためにレヘルペスフの 內容を家兔角膜に 接種せるも陰性に 終つてみ る. 又此のレアフタา性口內炎の傳染性細菌說を 裏書きする報告として Peiser は1926年に此の疾 患の流行を記载してみる. 又本症例に於て口腔 から得た菌種は普通の口腔內に於て常住する細 菌種と大した差違は認められない. 且つ奥澤の 多數の症例の報告に於ても，その細菌れよる絶 對的な病原性に關しては疑問とする點がある. 此の點何か他に吾人に未知の誘因が同時に作用 してみると考へられるのである。

細菌說に次で考へられるのは, 本症例に於て も見られる如く，消化器障礙說である. 之に就 ては Trusewitch はょアフタフ性口內炎の一特徵 は是々胃腸障礙に續發する事で郎ち胃酸過多症 のために監類の自家中瑇を起して アファフの發 生を招來すると云つてるる，ての中毒說を支持 する者は Forchheimer で彼は有毒物質が血行中 凡循環せられる結果っアフタา性口內炎を惹起す ると云つてみる.Kraus は本疾患と乳蒰との間 几密接な關係があると云つてなる.

其他 Seifert は新陳代謝障礙說を唱へて痛風 患者は慢性の經過を取るレアフタา性口內炎に罪 る素因を有すと云つてるる. Gerstenbergerはんへ ルペスフ性口內炎とレアフタา性口內炎とは同一 の原因を持ち，斯る患者に Vitamin B 製劑を投 與すると，100レパーセントフに全治すると述へ
てねる。

又本疾患は愿々月經中或は授乳期の婦人に發 現する傾きがある故に、性機能と關係があると も云はれてみる. 例へば Lang がレアフタフ性口 內炎を子宮性口內炎 Stomatitis uterina 之稃し てみるのがそれである。

Ivy は本疾患は神經性障礙に山るものと云つ てみる.斯の如く本疾患の原因に就ては種々样 くであり，其の歸一する處をみないが，臨床的 症狀及び經過については稍一賁共通するものを 認められる. 即ち輕度或は高度の發熱を伴つて 發病し，其の翌日に口腔粘膜特に齿敬に正型の レアフタフを發生する事が常で, 之は普通圓形も しくは卵圓形の踠豆大の淺在性潰瘍であり, 其 の周圍には赤出の邊緣があり, 潰痋の中央には

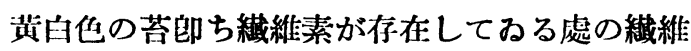
素性溶出物からなる溃痛である，之が领食，談 話の際に疼痛を起し，同時に他學的には口县が あり，又自覺的には疼痛の外に胃腸障礙を訴人 子.

かくて數日乃至10日後には漸次其の症狀は快 方に向ひ逐に治癒するもので, 不良な轉歸をと るものは殆んどなく偶々再柬する事がある，仵 し1887年に Hirtz は既に融合性レアフタフ性口內 炎の你在を唱へ，1912年に Therre は63荿の老 婦人が融合性レアフタフに篗つて，その合併症の ために死亡した事を報告してるる.此の外に咽 頭或は喉頭がレアフタフに侵される事がある. 此の場合には比較的に高度の哭下困難がある. Zuppinger はか」る下向性レアフタาの際には, 狹穾現像も亦層々起ると報告してみる.

次にレアフタフの組織病理に就ては, Fränkel, Aschoff, Kaufmann 等はっアフタフの組織はょヂ 
フテリーフの義膜に等しい構造を有して居ると 断言してるる.

Henoch はレアフタフは粘膜表屡に於ける繊維 素性の汪出物である之云つてるる.Kraus は粘 膜上皮居が消失して滲出物が發生して遂にしア フタフ と變るのであると云つてるる。

以上の諸說飞對し本例を考察すると，本症例 は同一家族上り 4 人の者がレアフタา性口内炎に 馡つて居る事より，之を原因的に考へる時先づ 第一飞傅染說が考へられる. 即ち 4 人の內, 最 初に罪患せる者上り順次に他の者に傅染せるも の之考へられる. 第二には，患者の生活環境よ り新陳代謝障礙說が考へられる゚. 郎ち, 患家の 職業は標問屋であり, 日支事變勃發以來食糧品 の一部は樽飞詰めて大陸に輸送する關係上樽の 需要は大なるものがある，その篇め商霣多忙を 極めた結果, 從來使用人と患者等とは食飭は別 であつたのが最近はその樣な事はなく，發有期 几ある若年の 4 人の者が使用人之同梯な食物を 捶らねばならなくなり，食飭の急變のために胃 晹障礙を起し, 加ふるに策養素の變動のために
新陳代謝障礙を合併し，てれが 4 人の者に共通 な因子之なつて兄尊姉妹が相前後して 性口内炎に程患せるものと思考される.

\section{結論}

本症例は同一家族の 4 人の發育期にある若年 者が殆んぞ時を同じくして輕度の發熱を以て டアフタา性口內炎に睢患せるもので, 發病部位 は口唇, 舌, 蒛鹋, 頓部, 硬口蓋の粘膜であつ て細菌學的檢索儿於ては何れ葡薂狀球菌, 連

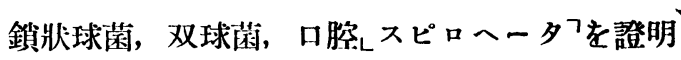
してるる.

血像に於ては多核白血球の筧多は認められな いが，何れも多少の淋巴球の増加老證明してる る.

治療法としては，何れも局所に 1日2四しオキ

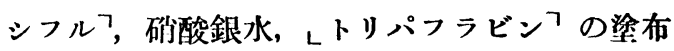
を行ひ，合嗽を厏行せしめ，且つレヴイタミンフ $\mathrm{B}$ ，レヴイタミンフ $\mathrm{C}$ 利を强力几內服及び注射せ しめた結果, 約 5 月後には總て全治せるもので ある。

\section{文㟧}

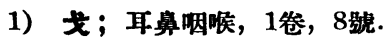

4) 社田; 耳鼻咽喉，8卷，3號.

7) 竹深；耳鼻咽喉，4告，6號.

10) 山下; 阪醫事誌，5兊，2號.

4卷, 11 號.

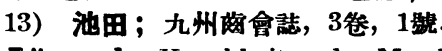

15) Mikulicz a. Lümmel; Krankheiten des Mundes. 1927.
2) 山川; 阪稫事誌, 3卷, 9號.

5) 楠; 日醫新報, 12卷.

8）滆地；耳鼻咽喉，7卷，8號.

11）管原；謴驗矮報，昭和17年，199號.
3）福盘；最新治療，6卷，6號. 6) 郡司; 耳鼻咽喉, 7卷, 8號.

9）㴋川；治療誌. 4卷, 2號. 12 ; 荒井; 耳悬咽啒,

16) Neumann u. Lehmann; Bakteriologie 